\title{
Investment climate of the territory: assessment problems
}

\author{
Tatiana Dyukina \\ St. Petersburg State University \\ St. Petersburg, Russia \\ E-mail: dtospb@mail.ru , t.dukina@spbu.ru
}

\author{
Valentina Kordovitch \\ St. Petersburg University of Management and Economics \\ Technologies \\ Institute of International Programs \\ Saint Petersburg, Russia \\ vkspb2002@mail.ru
}

\begin{abstract}
This article is devoted to problems of assessment of investment climate of the territory. She contains results of inventory of methods of assessment of investment climate of the territory. Authors have emphasized features of drawing up the most known ratings in the field of assessment of investment climate of regions of the country. Results of assessment of investment climate of regions of Russia in 2016 (on the example of the agrarian sector) in two options (with use of empirical data on 15 and 10 indicators) on the basis of methods are presented in article: the sums of places, standardization, scores (taking into account and without importance coefficient).
\end{abstract}

Keywords - investment climate, regions, assessment, problems, agrarian sector

\section{INTRODUCTION}

Researches in the field of assessment of investment climate of territories (regions and economic systems) have almost centenary history. At this particular time, at the beginning of the 20th century in the USA the international companies of "the big three" - Moody's, Standard and Poor (S\&P) Fitch Ratings which today are world leaders in the field of assessment of investment climate of regions and countries were born. Today the researches devoted to assessment of investment climate of territories (regions and economic systems), have specifics - branch orientation. So, today in world economic literature from the research point of view of assessment of investment climate of territories (regions and economic systems) the following spheres are the most popular: trade [for example, 11], tourism, transport infrastructure, geology (mining industry of the countries) [for example, 8], power (power plants, etc.) [for example, 3], agrarian sector.

After imposition of economic sanctions against the Russian Federation in August 2014 in Russia the paramount importance was gained by researches of assessment of investment climate of territories in the sphere of agriculture. In total with measures for introduction of some economic measures for protection of the Russian Federation, including the ban on import of some goods from the countries which have earlier established different restrictive measures against our country, Russia has increased the number of investments into agriculture which have put this branch on the way of forward growth of volumes of agricultural production (fig. 1).

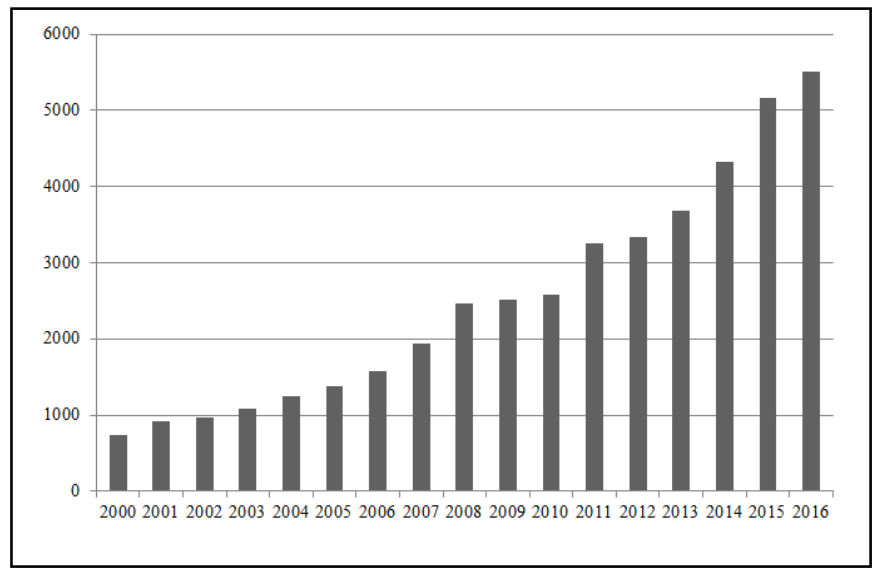

Fig. 1. Dynamics of production of agriculture of Russia in 2000 - 2016 (in actually operating prices), one billion rubles

Source: it is made by authors on the basis of data [15]

In agricultural branch from 2000 to 2016 it was annually made production on average for 2510.8 billion rubles, at the same time the outputs increased on average by $12.51 \%$ a year. Today agriculture is one of fast-growing sectors of economy of the Russian Federation. So, according to Federal State Statistics Service, in 2015, difficult for Russia, this branch was almost only, having the positive index of production (in the comparable prices) $2.6 \%$ to the level of previous year, and in $2016-4,8 \%[15]$.

Recently agriculture of Russia shows growth advancing GDP growth of Russia (fig. 2) that is in no small measure caused by the operating mode of the counter sanctions entered by the Russian Federation in response to sanctions of the western partners. 


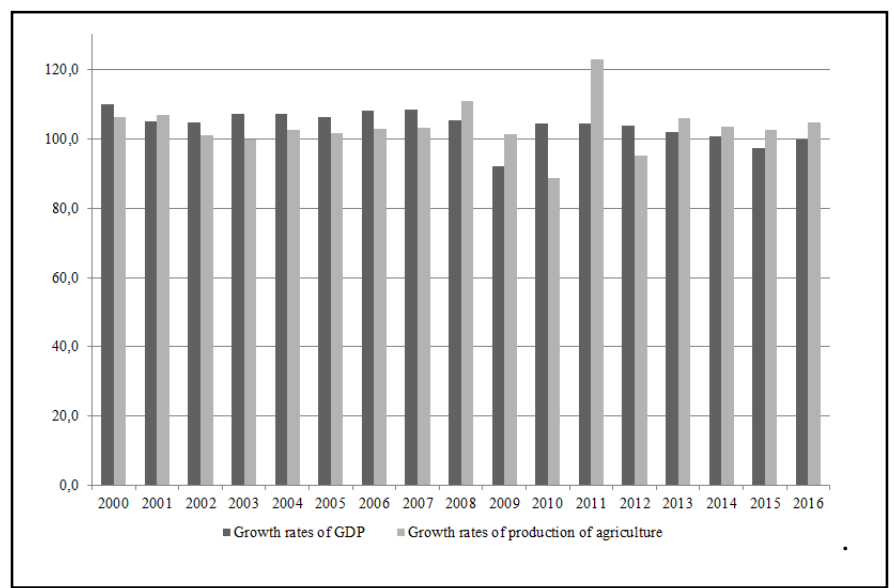

Fig. 2. Dynamics of growth rates of GDP (in real terms) and growth rates of production of agriculture of Russia in 2000 - 2016 (in the comparable prices), $\%$

Source: it is made by authors on the basis of data [15].

In recent years agriculture has received also powerful incentive for the development from the state: seasonal and universal crediting, obligatory state insurance of agriculture, increase in volumes of regional financing. However, the problem of shortage of investments from which the agroindustrial complex always suffered remains relevant and today. The solution of this problem and also the prospect of development of agriculture and accumulation of volumes of release of agricultural production fully depend on attracting investors to the sphere of agricultural production. For making decision on investments it is important to any investor to obtain objective data on the market: to carry out the analysis of the market environment, to study potential consumers and competitors, to estimate the volume, market capacity and also to weigh all possible investment risks.

Russia - the unique country having different climatic zones, variety of the landscapes differing in the heterogeneity, different population density, transport and logistic infrastructure, various social and economic status of regions. All these factors exert direct impact on development of agriculture. Attraction of investments into branch of agriculture to regions of the country requires implementation of timely, full and comprehensive assessment of investment climate of territories (regions) of the country and also drawing up their rating.

The research is the present purpose inventory of methods of assessment of investment climate of the territory, identification of problems which don't allow making true assessment of investment climate of the territory. Realization of the specified purpose has demanded the solution of the following research problems: to study foreign and domestic sources in which there is information on assessment of investment climate of the territory; to consider features of drawing up the most known ratings in the field of assessment of investment climate of regions; on the basis of methods: the sums of places, standardization, scores (in two options taking into account and without importance coefficient) to carry out assessment of investment climate of regions of
Russia in 2016 in two options (with use of 15 and 10 indicators).

\section{RESEARCH METHODS}

The following methods are applied to assessment of investment climate of regions in our research: a method of the sum of places, a standardization method, a score method in two options: taking into account and without importance coefficient. For the choice of the indicators characterizing investment climate of regions of Russia in 2016 also correlation and regression analysis has been used. Tabular and graphic methods are applied to evident representation of results of research.

\section{RESULTS OF A RESEARCH}

In branch of agriculture, in our opinion, today it is a little researches devoted to assessment of investment climate of territories (regions and economic systems). From the foreign researchers who have devoted the works to consideration of various aspects of this question it is possible to note works Cappelli, G., Yamaç, S.S., Stella, T., Negri, M., Confalonieri, R. [4], Hotra, V.V. [6], Kurowska, K., Kryszk, H. [9], Mandade, P., Bakshi, B.R., Yadav, G.D. [10], Patil, S., Aditya, Jha, A.K [12],Singh, R., Singh, A.P., Metri, B.A. [14], Trier, R. [17], Viaene, J., Van Lancker, J., Vandecasteele, B., De Neve, S., Reubens, B. [18].

A particular interest deserves the technique presented in research of institute of market economy of Danzig with assistance of Konrad Adenauer's Fund. Within the research assessment of investment climate of voivodeships and regions of Poland has been carried out. The Polish colleagues have allocated a number of factors which in combination with an optimum location of the region have created the best conditions for success of business activity of the companies of the region. For assessment of investment climate of the region they have chosen the factors characterizing advantages of a territorial location such as transport availability, the labour cost, quantity and quality of a manpower, market capacity is sold, extent of development of social and economic infrastructure, level of economic development and public finances, safety. Each of the specified factors has various importance in complex assessment of investment climate of the region. So, for example, the importance of transport availability at assessment of voivodeships has received $20 \%$, a manpower - $25 \%$, market capacity - 15\%, extent of development of economic infrastructure - 10\%, extent of development of social infrastructure - 5\%, safety level $5 \%$, and activity of voivodeships on improvement of investment climate $-20 \%$ [5].

The analysis of foreign and domestic literature on the studied question has also shown what in Russia is available more, than abroad, the researches devoted to various aspects of assessment of investment climate of the territory. Really, for our country this question is one of the most urgent now.

It should be noted that the majority of the western and domestic techniques of assessment of investment climate of the region represent assessment of solvency of the region on 
the basis of the analysis of various factors, such as recoverability and economic efficiency of investments; availability of crediting; the analysis of a political situation in the region; analysis of social and demographic position of the region; region infrastructure research, etc. For the analysis of solvency of regions statistical data from open sources and expert estimates of the leading analysts of rating agencies are used. In the researches each agency uses the author's scale of credit ratings which, as a rule, has alphabetic references.

Now in the Russian Federation the pool of the authoritative Russian specialized rating agencies and consulting companies having the author's techniques in the field of assessment of investment climate of regions is created.

For carrying out ratings in the field of assessment of investment climate of regions it is possible to carry to the most known techniques:

- the technique applied by drawing up National rating of a condition of investment climate in Russia by "The agency of strategic initiatives";

- the technique of assessment of investment climate of the region of Institute of Economy of the Russian Academy of Sciences (RAS);

- the technique applied by drawing up rating of investment attractiveness of regions of Russia "RAEkspert";

- the technique of assessment of investment attractiveness of the region of the National Rating Agency (NRA);

- the technique of assessment of investment attractiveness of the consulting company "Aurora Consulting".

A. The technique applied by drawing up National rating of a condition of investment climate in Russia by "The agency of strategic initiatives" [16]

The agency of strategic initiatives of promotion of new projects (The agency of strategic initiatives, ASI) - the Russian autonomous non-profit organization formed by the Government of the Russian Federation for realization of a package of measures in economic and social spheres. In particular, for promotion of priority projects, realization of actions for improvement of the enterprise environment in Russia, to development of professional staff, etc. the Chairman of the supervisory board is Vladimir Putin.

The National rating of a condition of investment climate created by ASI investigates activities of heads of territorial subjects of the Russian Federation for creating favourable conditions of business and reveals the best practician, and his results stimulate the competition in fight for investments at the regional level.

The methodology of drawing up rating includes three key elements: system of indicators, principles of collecting and data processing, method of calculation of results. When developing this methodology experience of the existing domestic and international ratings and other mechanisms of assessment of investment climate has been considered.

The rating consists of 45 indicators which are grouped in 17 factors making 4 directions: regulatory environment, institutes for business, infrastructure and resources, support of small business. Obtaining information on indicators is carried out by holding polls of businessmen and experts and also with use of statistical data.

Level of indicators in rating are the reduced and processed basic data brought for each indicator to a uniform scale from 0 to 100 where 0 - the worst possible measurement, 100 - the best. Level of factors are the average (weighed) values of points on indicators which enter factors. For example, the point for efficiency of the procedure of registration of the enterprises is formed on the basis of three indicators: average time of registration of legal entities, average number of the procedures necessary for registration of legal entities, satisfaction with activities for the state registration of legal entities.

Level of the directions are the average (weighed) values of factors (points on indicators), entering the direction. For example, the point for the regulatory environment is formed of five factors: efficiency of procedures of registration of the enterprises, efficiency of procedures for issue of construction licences, efficiency of procedures for registration of the property rights, efficiency of procedures for issue of licences, efficiency of procedures for connection of the electric power. Level of the integrated index is a score in all four directions of Rating.

\section{B. Technique of assessment of investment climate of the region of Institute of Economy of the Russian Academy of Sciences (RAS) [2]}

For assessment of investment climate of the region of IE RAS uses multiple-factor model (all 75 different factors are analysed) regional investment climate: 65 factors are estimated in the expert way; 10 factors statistical which come down in seven blocks: "A" — factors of economic potential; "B" - managing conditions; " $C$ " - formation of the market environment; - political factors; " $D$ " - social and sociocultural factors; "E" - organizational and legal factors; - financial factors. The factors determined by expert estimates are estimated by a six-ball scale: $0,1,2,3,4,5$. For holding expert poll selection which can be divided conditionally on 5 into five segments is created: 1) representatives of scientific community; 2) workers of the sphere of the bank sphere (crediting); 3) heads of small and medium-sized enterprises; 4) employees of bodies of regional and federal state executive power; 5) heads of the large industrial enterprises of the region.

Each region is compared to other regions on a certain indicator, on a comparison result the point is appropriated to the region. The region with the best indicators gets 5 points; the region which matters the smallest among all - 0 ; average values of indicators are estimated at 2.5 points. Other points treat also, proceeding from proportions. The received average sizes from expert estimates on each factor and each of statistics are multiplied by "weight" (extent of influence of 
this factor on investment climate). "Weight" are established by experts on the basis of expert interviews of investors, representatives of the executive authorities, the ministries and departments dealing with problems of investments. Set of the average (weighed) estimates on all factors is summarized and represents a summary indicator of investment climate of the territory. Further the serial scale of an arrangement of regions on decrease of an indicator of investment climate of the territory which is the rating of regions on the level of investment climate is formed.

\section{Rating of investment attractiveness of regions of Russia "RA-Ekspert" [13]}

Rating agency "RA-Ekspert" (RAEKS-Analitika) — the largest and most authoritative Russian credit rating agency.

"RA-Ekspert" in 1996 has for the first time developed own technique of drawing up rating of investment attractiveness of regions of Russia. At her development both the Russian, and foreign experience of the analysis and comparison of investment attractiveness of various countries was considered. From 1996 to 2016 in process of change of a social and economic situation in Russia and also development of the legislative base the technique several times changed.

The main sources of information for the analysis: Rosstat, EMISS, Ministry of Finance of the Russian Federation, Federal Treasury, Bank of Russia, Ministry of Internal Affairs of the Russian Federation, Federal Tax Service of the Russian Federation, Ministry of Natural Resources and Environmental Protection of the Russian Federation, Ministry of Telecom and Mass Communications of the Russian Federation.

The agency analyses investment attractiveness of Russian regions through two rather independent characteristics: investment potential and investment risk. The ratio of these sizes has formed the basis of designation of rating categories: investment potential is designated by figures from 1 (high) up to 3 (low), and investment risk has received alphabetic reference from And (the minimum risk) to D (very high risk).

\section{Technique of assessment of investment attractiveness of the region of the National Rating Agency (NRA) [7]}

The investment attractiveness of the region is defined in NRA rating as set of the factors influencing expediency, efficiency and level of risks of investment investments in the territory of this region. These factors are an active background for all investment projects realized in the territory of the region influence risk and profitability of these projects. The investment attractiveness of the region consists of several factors, each of which can be estimated by means of selection for him certain variables.

The rating of National Rating Agency considers 7 factors of regional investment attractiveness: 1) security of the region with natural resources and quality of the environment in the region; 2) region manpower: main characteristics of a manpower of the region; 3) assessment of a condition of regional infrastructure: including transport, power, telecommunication, housing, financial; 4) domestic market of the region (potential of regional demand): the level of development of domestic market of the region (including scales of sectors of retail trade and paid services), the located income and purchasing power of the population of the region; 5) production potential of regional economy: cumulative results and features of economic activity of the enterprises working in the region; 6) institutional environment and sociopolitical stability: expert assessment of efficiency of the regional legislation regulating interaction of the power and investors, expert assessment of usefulness of the regional tax law (existence of tax benefits and a possibility of their receiving), level of social and criminal tension in the region; 7) financial stability of the regional budget and enterprises of the region: a condition of public finances in the region and also assessment of a financial position of the enterprises of the region.

For the analysis of these factors analysts of NRA have made 53 indicators (proxy and variables). The indicators used in NRA technique for assessment of factors of investment attractiveness of the region can be divided into three groups: 1) statistics (are traditionally used for assessment of the majority of factors of investment attractiveness of regions the analysis of secondary sources: Rosstat, data of the ministries and departments, etc.); 2) quantitative poll in the form of telephone or personal interviews of representatives of enterprise community; 3) expert interviews with representatives of investment and scientific community.

Rating assessment of investment attractiveness of the region is appropriated on the special scale divided into three big categories, in each of which three levels are allocated.

\section{E. Assessment of investment attractiveness of the consulting company "Aurora Consulting" [1]}

Assessment of investment attractiveness of one of the leading consulting companies which are actively advising participants of the financial market of Russia on a wide range of professional questions of Aurora Consulting assumes accounting of the following indicators: payback period; current cost of future income; profitability rate; the risk factors capable to have significant effect on results.

In our opinion, the difference in the considered approaches to assessment of investment climate of the territory is caused, first of all, by different understanding of a definition "investment climate of the territory" and insertion in her various contents. In this regard it is advisable to note that the definition "investment climate of the territory" is structurally interconnected with definitions "investment attractiveness of the territory" and "investment potential of the territory" that predetermines the main lines of their similarity. However noted definitions are qualitatively various and have essentially distinctive features.

According to us, the investment attractiveness of the territory (the region, branch, the enterprise) is the property of the territory which is characterized by volume indicators (and/or efficiency degrees) the enclosed investments (in general to the region or in this or that branch, the enterprise) or, in other words, as far as this or that territory is attractive to investors (the indicator can be defined in dynamics: last, real and future); investment potential of the territory represents set 
of all available opportunities, means of the territory (in any sphere) promoting attraction of investments; investment climate of the territory - conditions, Wednesday in which investment processes, and degree of her usefulness proceed.

Despite relevance of identification of essence and also evaluating investment climate of the territory (regions) the Russian Federation, still doesn't exist legislatively fixed uniform as, however, and fixed at the regional level, definitions of a definition "investment climate of the territory". The lack of a normative definition of a definition doesn't deny "investment climate of the territory" in our country, and even on the contrary, generates a lot of researches in the field of a conceptual framework of "investment climate of the territory" and development of different approaches to assessment of investment climate of the territory.

As a result, the investment climate of the territory and his assessment in various options of her embodiment are an object of research of many domestic scientists. At the same time definitions of a definition of "investment climate of the territory" and his assessment, also as well as in works of foreign researchers, vary depending on a work context. Approaches of the Russian scientists to assessment of investment climate of the territory are characterized by considerable differences on the relation to each other as they are caused by different views of researchers on essence of the specified definition and also a set (system) of the factors defining investment climate of the territory.

It should be noted also that on inclusion of these or those factors (a set of the factors) defining investment climate of the territory in a technique of assessment of investment climate of the territory, exert impact not only knowledge, skills, experience, but also personal preferences of scientistsresearchers, often even without necessary use of specific tools of the analysis, such as, the regression, correlation, dispersive analysis and others. As a result, often assessment of investment climate of the territory is carried out with use of set of the factors having high mutual correlation of the explaining variables - multicollinearity that distorts results of the carried-out analysis and doesn't allow receiving true assessment of investment climate of the territory. Told it is visually shown in tables 1 and 2 received by authors of the present article on the basis of assessment of these indicators characterizing investment climate of regions of Russia in 2016. In table 1 results of assessment of investment climate of regions of Russia in 2016 on 15 indicators, and are presented in table 2 - on 10 indicators. The following methods are applied to completeness of assessment of investment climate of regions in our research: a method of the sum of places, a standardization method, a score method in two options: taking into account and without importance coefficient.

On the basis of the analysis of these tables 1 and 2 it is possible to tell that use of various indicators (a set of indicators) significantly changes a picture of investment climate in regions of the country.
TABLE I. ASSESSMENT OF INVESTMENT CLIMATE OF REGIONS OF RUSSIA IN 2016 WITH USE OF 15 INDICATORS

\begin{tabular}{|c|c|c|c|c|}
\hline Location & $\begin{array}{c}\text { Method of } \\
\text { the sum of } \\
\text { places }\end{array}$ & $\begin{array}{l}\text { Standardization } \\
\text { method }\end{array}$ & $\begin{array}{l}\text { Method of } \\
\text { score } 1\end{array}$ & $\begin{array}{c}\text { Method of } \\
\text { score 2Table } \\
\text { Head }\end{array}$ \\
\hline 1 & $\begin{array}{l}\text { Krasnodar } \\
\text { Krai }\end{array}$ & Krasnodar Krai & $\begin{array}{c}\text { Krasnodar } \\
\text { Krai }\end{array}$ & $\begin{array}{c}\text { Krasnodar } \\
\text { Krai }\end{array}$ \\
\hline 2 & $\begin{array}{l}\text { Republic } \\
\text { of } \\
\text { Tatarstan }\end{array}$ & $\begin{array}{l}\text { Republic of } \\
\text { Tatarstan }\end{array}$ & $\begin{array}{l}\text { Rostov } \\
\text { region }\end{array}$ & Rostov region \\
\hline 3 & $\begin{array}{l}\text { Rostov } \\
\text { region }\end{array}$ & Rostov region & $\begin{array}{c}\text { Republic of } \\
\text { Tatarstan }\end{array}$ & $\begin{array}{c}\text { Republic of } \\
\text { Tatarstan }\end{array}$ \\
\hline 4 & $\begin{array}{l}\text { Belgorod } \\
\text { region }\end{array}$ & Voronezh region & Moscow & Moscow \\
\hline 5 & $\begin{array}{l}\text { Voronezh } \\
\text { region }\end{array}$ & Stavropol Krai & $\begin{array}{l}\text { Voronezh } \\
\text { region }\end{array}$ & $\begin{array}{l}\text { Voronezh } \\
\text { region }\end{array}$ \\
\hline 6 & $\begin{array}{l}\text { Kursk } \\
\text { region }\end{array}$ & Belgorod region & $\begin{array}{c}\text { Stavropol } \\
\text { Krai }\end{array}$ & $\begin{array}{c}\text { Stavropol } \\
\text { Krai }\end{array}$ \\
\hline 7 & $\begin{array}{l}\text { Stavropol } \\
\text { Krai }\end{array}$ & $\begin{array}{c}\text { Republic of } \\
\text { Bashkortostan }\end{array}$ & Altai Krai & Altai Krai \\
\hline 8 & $\begin{array}{l}\text { Moscow } \\
\text { region }\end{array}$ & Moscow & $\begin{array}{l}\text { Belgorod } \\
\text { region }\end{array}$ & $\begin{array}{l}\text { Belgorod } \\
\text { region }\end{array}$ \\
\hline 9 & $\begin{array}{l}\text { Samara } \\
\text { region }\end{array}$ & Tyumen region & Sevastopol & Sevastopol \\
\hline 10 & $\begin{array}{l}\text { Saratov } \\
\text { region }\end{array}$ & Altai Krai & $\begin{array}{l}\text { Tyumen } \\
\text { region }\end{array}$ & $\begin{array}{l}\text { Tyumen } \\
\text { region }\end{array}$ \\
\hline
\end{tabular}

TABLE II. ASSESSMENT OF INVESTMENT CLIMATE OF REGIONS OF RUSSIA IN 2016 WITH USE OF 10 INDICATORS

\begin{tabular}{|c|c|c|c|c|}
\hline Location & $\begin{array}{l}\text { Method of } \\
\text { the sum of } \\
\text { places }\end{array}$ & $\begin{array}{c}\text { Standardization } \\
\text { method }\end{array}$ & $\begin{array}{l}\text { Method of } \\
\text { score } 1\end{array}$ & $\begin{array}{c}\text { Method of } \\
\text { score 2Table } \\
\text { Head }\end{array}$ \\
\hline 1 & $\begin{array}{l}\text { Belgorod } \\
\text { region }\end{array}$ & Krasnodar Krai & $\begin{array}{c}\text { Krasnodar } \\
\text { Krai }\end{array}$ & $\begin{array}{c}\text { Krasnodar } \\
\text { Krai }\end{array}$ \\
\hline 2 & $\begin{array}{l}\text { Krasnodar } \\
\text { Krai }\end{array}$ & $\begin{array}{c}\text { Republic of } \\
\text { Tatarstan }\end{array}$ & Sevastopol & Sevastopol \\
\hline 3 & $\begin{array}{l}\text { Kursk } \\
\text { region }\end{array}$ & Voronezh region & $\begin{array}{l}\text { Voronezh } \\
\text { region }\end{array}$ & $\begin{array}{l}\text { Voronezh } \\
\text { region }\end{array}$ \\
\hline 4 & $\begin{array}{l}\text { Bryansk } \\
\text { region }\end{array}$ & Sevastopol & $\begin{array}{l}\text { Rostov } \\
\text { region }\end{array}$ & Rostov region \\
\hline 5 & $\begin{array}{l}\text { Republic } \\
\text { of } \\
\text { Tatarstan }\end{array}$ & Rostov region & $\begin{array}{l}\text { Republic of } \\
\text { Tatarstan }\end{array}$ & $\begin{array}{l}\text { Republic of } \\
\text { Tatarstan }\end{array}$ \\
\hline 6 & $\begin{array}{l}\text { Voronezh } \\
\text { region }\end{array}$ & Belgorod region & $\begin{array}{l}\text { Belgorod } \\
\text { region }\end{array}$ & $\begin{array}{l}\text { Belgorod } \\
\text { region }\end{array}$ \\
\hline 7 & $\begin{array}{l}\text { Rostov } \\
\text { region }\end{array}$ & Bryansk region & Moscow & Moscow \\
\hline 8 & $\begin{array}{l}\text { Lipetsk } \\
\text { region }\end{array}$ & Stavropol Krai & $\begin{array}{l}\text { Bryansk } \\
\text { region }\end{array}$ & $\begin{array}{c}\text { Bryansk } \\
\text { region }\end{array}$ \\
\hline 9 & $\begin{array}{l}\text { Moscow } \\
\text { region }\end{array}$ & Kursk region & $\begin{array}{l}\text { Stavropol } \\
\text { Krai }\end{array}$ & $\begin{array}{c}\text { Stavropol } \\
\text { Krai }\end{array}$ \\
\hline 10 & $\begin{array}{l}\text { Stavropol } \\
\text { Krai }\end{array}$ & Lipetsk region & $\begin{array}{l}\text { Sakhalin } \\
\text { region }\end{array}$ & $\begin{array}{l}\text { Sakhalin } \\
\text { region }\end{array}$ \\
\hline
\end{tabular}

Besides, data of these tables demonstrate that various methods of the analysis applied to assessment of investment climate of territories also yield results excellent from each other. 


\section{CONCLUSION}

By results of the conducted research it is possible to draw the following conclusions.

The difference in the considered approaches to assessment of investment climate of the territory is caused, first of all, by different understanding of a definition "investment climate of the territory" and insertion in her various contents.

The picture of investment climate in regions of the country depends on use of various indicators (a set of indicators) when evaluating investment climate.

Various methods of the analysis (a method of the sum of places, a standardization method, a score method in two options: taking into account and without importance coefficient), applied to assessment of investment climate of territories, also yield results excellent from each other regions in ratings appear on different places.

Indicators, characterizing investment climate of the territory, and not having high mutual correlation of the explaining variables, it is possible to choose on the basis of application of the correlation and regression analysis for the choice of indicators.

Thus, for receiving true assessment of investment climate of the territory it is necessary to use a set (systems) of the factors which don't have high mutual correlation of the variables. Besides, it is required to prove application of this or that method of the analysis in each case as results of such analysis can be various.

\section{References}

[1] Assessment of investment attractiveness of the, URL: http://www.aurora-consult.ru/services/appraising/investicionnyh_ proektov.html project

[2] Assessment of investment climate of the region: technique [An electronic resource]//nstitute of Economy of the Russian Academy of Sciences (RAS), URL: http://inecon.org

[3] Bakhshi, R., Sadeh, J. "Economic evaluation of grid-connected photovoltaic systems viability under a new dynamic feed-in tariff scheme: A case study in Iran," Renewable Energy, 2018, 119, pp. 354364

[4] Cappelli, G., Yamaç, S.S., Stella, T., Negri, M., Confalonieri, R. "Are advantages from the partial replacement of corn with second-generation energy crops undermined by climate change? A case study for giant reed in northern Italy," Biomass and Bioenergy, 2015, 80, pp. 85-93
[5] Die Investitionsattraktivität der Wojewodschaften und Subregionen Polens, Danzig, 2009 // Erstellung des Forschungsberichts am Danziger Institut für Marktwirtschaft in Zusammenarbeit mit der KonradAdenauer-Stiftung., URL: www.kas.de/wf/doc/kas_19084-544-1-30.pdf

[6] Hotra, V.V. "Current state, factors of influence and directions for further activization of investment activity in agriculture,"Actual Problems of Economics, 2015, 168(6), A114, pp. 114-121

[7] Investment attractiveness of regions: assessment technique [An electronic resource]//National Rating Agency (NRA), URL: http://www.ra-national.ru

[8] Jara, J.J. "Determinants of country competitiveness in attracting mining investments: An empirical analysis," Resources Policy, 2017, 52, pp. 6571

[9] Kurowska, K., Kryszk, H. "Influence of agricultural and forest land protection on development of investment and construction process in Poland," International Multidisciplinary Scientific GeoConference Surveying Geology and Mining Ecology Management, 2016, SGEM. 2, pp. 485-492

[10] Mandade, P., Bakshi, B.R., Yadav, G.D. "Ethanol from Indian agroindustrial lignocellulosic biomass-a life cycle evaluation of energy, greenhouse gases, land and water," International Journal of Life Cycle Assessment, 2015, 20(12), pp. 1649-1658

[11] Öner, Ö. "Retail city: the relationship between place attractiveness and accessibility to shops," Spatial Economic Analysis. 2017, 12(1), pp. 7291

[12] Patil, S., Aditya, Jha, A.K. "Role of financial agencies in integrating small farmers into a sustainable value chain: A synthesis-based on successful value chain financing efforts," Current Science, 2016, 110(11), pp. 2082-2090

[13] Rating of investment attractiveness of regions of Russia: concept of the project [An electronic resource] //Expert Rating Agency, URL: http://raexpert.ru/ratings/ regions/concept/

[14] Singh, R., Singh, A.P., Metri, B.A. "Key performance indicators for the organized farm products retailing in India," Decision Management: Concepts, Methodologies, Tools, and Applications, 2017, 3-4, pp. 13161329

[15] Socio-economic indexes of the Russian Federation in 1991 - 2016, URL: http://www.gks.ru/wps/wcm/connect/rosstat_main/rosstat/ru /statistics/publications/catalog/doc_1270707126016

[16] The national rating of a condition of investment climate in territorial subjects of the Russian Federation: methodology [An electronic resource] //Agency of strategic initiatives, URL: http://asi.ru/investclimate/rating/

[17] Trier, R. "Review of international experience with public-private partnership in the irrigation subsector," Irrigation and Drainage, 2014, 63(2), pp. 212-220

[18] Viaene, J., Van Lancker, J., Vandecasteele, B., De Neve, S., Reubens, B. "Opportunities and barriers to on-farm composting and compost application: A case study from northwestern Europe," Waste Management, 2016, 48, pp. 181-192 